\title{
The Potential Capacity of Ten Plant Extracts on Calcium Oxalate Formation In -Vitro Study
}

\author{
Beghalia Mohamed* \\ Laboratory of Agronomy and Ecology Department of Biology, Tissemsilt University Center, Algeria
}

Submission: May 18, 2019; Published: July 25, 2019

"Corresponding author: Beghalia Mohamed, Laboratory of Agronomy and Ecology Department of Biology, Institute of Technology, Tissemsilt University Center, Algeria

\section{Introduction}

Medicinal plants are still a source of medical care in developing countries in the absence of a modern medical system. Morocco is one of the Mediterranean countries with a long medical tradition and traditional know-how based on medicinal plants. Indeed, traditional medicine has always occupied an important place in the traditions of medication in Morocco; the rural commune of Imi n'Tlit is a concrete example. However, the intensive exploitation of plant species for medicinal purposes may become harmful if it exceeds the threshold of sustainable regeneration by the resources used [1].

Our work is a contribution to physiotherapy plants used by the local population of the Sahara in traditional pharmacognosy, in order to identify plant species that act mainly on the inhibition of formation of urinary lithiasis. To our knowledge, there is no regulation of the collection of medicinal species in the forest; therefore, strong harvest pressure can lead to reduction and / or loss of biodiversity, decreased productivity.

The meaning of the term ethnoscience has itself evolved and moreover it does not mean the same thing in different anthropological traditions. In the Anglo-Saxon tradition, it refers mainly to the study of knowledge and popular classifications while in France it also includes the know-how. But for both, the methodological principles remain the same: the knowledge and the practices are analyzed:

1) From the semantic categories of the populations studied;

2) These categories are confronted with those provided by the different scientific disciplines to which we must call, which belong as much to the biological sciences as to the human sciences: botany, chemistry, linguistics [2].

In botany and pharmacy, medicinal plants are known to offer, through their administration, a beneficial and therapeutic effect on the body. Employed since the earliest antiquity, often in relation to magical practices, their real properties have, at any time, exaggerated, or denied, or distorted according to the beliefs in force. In modern times, the biochemical and organic analysis methods, as well as those of plant physiology, have made it possible to begin a scientific sorting in the mass of actions attributed to the simple, destroying certain legends, but firmly establishing certain empirical uses old [3].

Many remedies from traditional medicine plants contain active ingredients whose effects can be demonstrated pharmacologically; and the biological activity of these plant extracts can always be related to that of the constituents that have been identified. The active extracts detected during a screening are often subject to other biological tests in order to specify the pharmacological activity. Each work aims to elucidate biological, pharmacological and clinical approaches for screening of active natural substances, in addition, it is a scientific approach is well described in order to find pharmacologically active substances from plant extracts. of plants are designed to be used without the intervention of a physician and to be administered in a specified dosage and dosage, orally, externally, or by inhalation. The therapeutic indication, strictly worded, must be preceded by the words "traditionally used in" to attest to the fact that these indications have not been rigorously demonstrated [4]

\section{Results and Discussion}

This present relates to the study of the effects of inhibitors of medicinal plant extracts on crystallization of calcium oxalate in order to enhance their therapeutic potential. The formation of the calculations involves different phases of calcium oxalate lithogen: nucleation, crystal growth, aggregation \& particle retention.

This study makes it possible to take stock of the therapeutic approaches to adopt depending on the type of involvement of the urinary tract and the diversity of medicinal plants that are very much in nature and most often used by traditional healers and herbalists for treatment of these pathologies. Most of the plant extracts selected in our work have proved effective in inhibiting 
calcium oxalate, the major component in urinary stones. Indeed, the extracts of the following plants: Erica multiflora, Erica arborea, Ammodaucus leucotrichus, Ajuga iva, Globularia alypum (Roots), Stipa tenacissim, Globularia alypum (Flowers), Chamaerops humilis, Atriplex halimus, Tetraclinis articulata, have proved effective for inhibiting the formation of calcium oxalate monohydrate crystals.

It should be noted that the extract of Erica multiflora has, according to our results, the highest antilithic potential. This plant is often used in eastern Morocco as an alternative therapeutic tool to treat hyperlipidemia. It is also used in folk medicine as a diuretic and antiseptic. The phytochemical study shows that tannins, flavonoids and proanthocyanidins are the main compounds of flower extracts [5]. On the other hand, the Ammodaucus leucotrichus extract also shows a high inhibition of calcium oxalate crystallization unlike Tetraclinis articulata. Ammodaucus leucotrichus is used in North African countries as a condiment or spice. It is used in traditional medicine for the treatment of cold, fever, digestive disorders etc. [6].

Note that the growth of crystals is the key step in the formation of stones. It should be noted that the driving force of crystallization is the reduction of the energy potential of the molecules bound together. It begins in a supersaturated liquid by the formation of clusters [5]. In addition, nucleation is the formation of a crystal phase in a solution. It is an essential step in the formation of kidney stones $[7,8]$. Finally, among the plant extracts that have developed very potent inhibitory effects on the crystallization of calcium oxalate, we mention Ammodaucus leucotrichus which acts at the stages of nucleation, growth \& aggregation. Erica multiflora inhibits nucleation and crystal growth, but not aggregation [9].

The classification of the plants studied according to their inhibitory capacity is as follows: Erica multiflora

I. Erica arborea

II. Ammodaucus leucotrichus

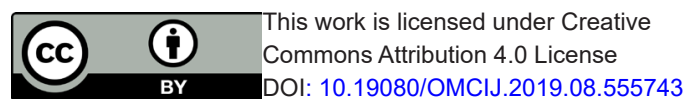
III. Ajuga iva
IV. Globularia alypum (Roots)
V. Stipa tenacissim
VI. Globularia alypum (Flowers)
VII. Chamaerops humilis
VIII. Atriplex halimus
IX. Tetraclinis articulata [10].

\section{References}

1. Tabuti J R S, Lye K A, Dhillion S S (2003) Traditional herbal drugs of Bulamogi, Uganda: plants, use and administration. J Ethnopharmacol 88 (1): 19-44.

2. Friedbeg C (1970) Analyse de quelques groupements de végétaux comme introduction à l'étude de la classification botanique bunaq, in Echanges et Communications, Mélanges offerts à Claude. Lévi-Strauss $2: 1092-1131$.

3. Larousse Encyclopédie MEMO, 1999.

4. Lahlou M (2003) Biological and Pharmacological Approaches to the Screening and Evaluation of Natural Products. J Thérapie 58(6): 535539.

5. Bruneton J (1987) Eléments de phytochimie et de pharmacognosie. In : Eléments de phytochimie et de pharmacognosie, Technique \& Documentation. Lavoisier (Ed) pp 136-162.

6. Muckensturm B, Diyani F, Le Nouen D , Fkih Tetouani S, Reduron J (1997) Ammolactone a guaianolide from a medicinal plant, Ammodaucus leucotrichus. Phytochem 44(5): 907-910.

7. Finlayson B (1978) Physicochemical aspects of urolithiasis. Kidney Int 13(5): 344-360.

8. Khan S R, Byer K J, Thamilselvan S, Hackett R L, McCormack W T, et al. (1999) Crystal-cell interaction and apoptosis in oxalate-associated injury of renal epithelial cells. J Am Soc Nephrol 10(14): S457-463.

9. Beghalia M, Ghalem S, Allali H, Belouatek A, Marouf A (2008) Screening for Anti-crystallisation Calcium Oxalate Urolithiasis Activity in Algerian Plants. Malaysian J Biochem Mol Biol 16(1): 11-15.

10. Beghalia M, Ghalem S, Allali H, Belouatek A, Marouf A (2008) Inhibition of calcium oxalate monohydrate crystal growth using Algerian medicinal plants. J Med Plants Res 2(3) : 066-070.

\begin{tabular}{l} 
Your next submission with Juniper Publishers \\
will reach you the below assets \\
- Quality Editorial service \\
- Swift Peer Review \\
- Reprints availability \\
- E-prints Service \\
- Manuscript Podcast for convenient understanding \\
- Global attainment for your research \\
- Manuscript accessibility in different formats \\
( Pdf, E-pub, Full Text, Audio) \\
- Unceasing customer service \\
Track the below URL for one-step submission \\
https://juniperpublishers.com/online-submission.php \\
\hline
\end{tabular}

